\title{
The Role of Exercise on L-Arginine Nitric Oxide Pathway in Chronic Heart Failure
}

\author{
A.C. Mendes-Ribeiro* ${ }^{* 1,2}$, G.E. Mann $^{3}$, L.R. de Meirelles ${ }^{1}$, M.B. Moss $^{1}$, C. Matsuura ${ }^{1}$ and \\ T.M.C. Brunini ${ }^{1}$
}

\author{
${ }^{I}$ Departamento de Farmacologia e Psicobiologia, Instituto de Biologia, Av. 28 de Setembro 87 CEP 20551-030, Rio de \\ Janeiro, Brazil \\ ${ }^{2}$ Disciplina de Farmacologia, Departamento de Ciências Fisiológicas, Universidade Federal do Estado do Rio de \\ Janeiro, Rio de Janeiro, Brazil \\ ${ }^{3}$ Cardiovascular Division, School of Biomedical and Health Sciences, King's College London, Guy's Campus, London, \\ $U K$
}

\begin{abstract}
Chronic heart failure (CHF) is a pathological state with high morbidity and mortality and the full understanding of its genesis remain to be elucidated. In this syndrome, a cascade of neurohormonal and hemodynamic mechanisms, as well as inflammatory mediators, are activated to improve the impaired cardiac function. Clinical and experimental observations have shown that $\mathrm{CHF}$ is associated with a generalized disturbance in endothelium-dependent vasodilation, which may contribute to the progression of ventricular and vascular remodelling in this syndrome. There is also accumulating evidence that disturbances in nitric oxide (NO) availability is involved in the development of heart failure at the systemic and cardiac levels. NO is a ubiquitous signalling molecule which causes potent vasodilation, inhibits platelet activation and regulates the contractile properties of cardiac myocytes. It is generated from the amino acid L-arginine via constitutive and inducible isoforms of the enzyme NO synthase (NOS). There is evidence that exercise, a nonpharmacological tool, improves symptoms, fitness $\left(\mathrm{VO}_{2 \text { peak }}\right)$, quality of life and $\mathrm{NO}$ bioavailability in CHF population. This review examines different aspects of the L-arginine-NO pathway and inflammation in the physiopathology of CHF and highlights the important beneficial effects of exercise in this disease.
\end{abstract}

Keywords: Nitric oxide; L-arginine; Heart failure; Blood cells, Endothelium, Exercise.

\section{INTRODUCTION}

Chronic heart failure $(\mathrm{CHF})$ is a clinical syndrome caused by an abnormality of the heart and diagnosed by a characteristic patterns of haemodynamic, renal and hormonal responses [1]. The prevalence of this disease is high throughout the world, with $50 \%$ of patients dying within four years and of $50 \%$ of patients with severe heart failure dying within one year [2].

Endothelium-dependent dilation of resistance vessels in response to acetylcholine is impaired in heart failure and related to the clinical severity of the disease [3, 4]. Endothelial dysfunction seems to contribute to the high vascular resistance in the systemic and pulmonary vascular beds of patients with chronic heart failure [3-5]. Accumulating evidence suggests that endothelial dysfunction may result from a decreased release of nitric oxide (NO) or an enhanced inactivation of this bioactive mediator [6].

In mammalian cells, NO is formed from the terminal guanidino nitrogen atom of L-arginine by a family of NOS

*Address correspondence to this author at the Av 28 de setembro 87, Departamento de Farmacologia e Psicobiologia, Instituto de Biologia Centro Biomédico, Universidade do Estado do Rio de Janeiro, Rio de Janeiro, 20551-030, Brazil; Tel: 005521 2587-6141; Fax: 0055212587 6808; E-mail: cribeiro@physiol.ox.ac.uk enzymes with characteristics of cytochrome P-450 reductase [7-9]. The principal mechanism of action of NO is to interact with heme moiety of guanylyl cyclase, increasing the production of intracellular cyclic guanosine monophosphate (cGMP) $[9,10]$. Membrane transport of the precursor Larginine is essential for physiological NO production and alterations in transport may in part help explain several of the pathological changes observed in CHF [6].

Increasing evidence has demonstrated that habitual physical activity can reduce the risk of cardiovascular disease [11]. Indeed, a direct correlation of the amount of exercise performed and a reduction in mortality due to cardiovascular disease has been reported in middle-aged and elderly populations [12].

This review aims to provide an overview of clinical and experimental data on the role of L-arginine-nitric oxide pathway and inflammation in the pathophysiology of CHF and the potential beneficial effects of exercise in this disease.

\section{PATHOPHYSIOLOGY OF CHRONIC HEART FAILURE}

$\mathrm{CHF}$ is a common and complex clinical syndrome whose incidence and prevalence is increasing world-wide [13]. CHF results from structural or functional cardiac disorders, leading to an impaired ability of the ventricle to fill with or 
eject blood. The cardinal manifestations of CHF are dyspnea and fatigue, which may limit exercise tolerance, and fluid retention, which may lead to pulmonary congestion and peripheral edema [1]. Both abnormalities can impair the functional capacity and quality of life of affected individuals, but they do not necessarily dominate the clinical picture at the same time. Some patients have exercise intolerance but little evidence of fluid retention, whereas others complain primarily of edema and report few symptoms of dyspnea or fatigue [2, 14].

Abnormal left ventricular systolic function from any cause appears to stimulate compensatory mechanisms to maintain cardiac output, systemic blood pressure and perfusion to vital organs. Most important among these are: (1) the Frank-Starling mechanism (i.e. the ventricle responds to an increased preload by enhancing its contraction; (2) ventricular hypertrophy with or without chamber dilation; and (3) neurohormonal activation [13-15].

Many neurohormonal systems are activated during chronic heart failure, such as the renin-angiotensinaldosterone system, sympathetic nervous system, endothelin and vasopressin, which lead to vasoconstriction and water and sodium retention $[13,15,16]$. Neuroendocrine systems are interactive and integrated with the brain, kidneys, heart and periphery, playing a role in the onset and progression of heart failure. Despite presumed initial circulatory homeostasis, prolonged neurohormonal activation may become highly maladaptive, contributing not only to increased afterload and reduced cardiac output but also causing necrosis and death of myocardial cells $[13,15,16]$.

The kidney plays a central role in salt and water retention in heart failure. A significant reduction in glomerular filtration rate accompanies impaired cardiac output and is caused by reduced arterial pressure and by constriction of the preglomerular arterioles in response to increased sympathetic activity and angiotensin II production [13, 15, 17]. This reduction in the glomerular filtration rate reduces sodium delivery to the nephron and, associated with direct actions of angiotensin II on tubular sodium reabsorption, may cause sodium and water retention $[17,18]$. The kidney synthesises rennin, protease kallikrein and prostaglandins, which are increased during chronic heart failure [19, 20].

Whereas neurohormonal factors have been extensively studied, the impact of local factors regulating peripheral vasomotor tone and tissue perfusion in chronic heart failure has been poorly defined. Clinical and experimental observations have demonstrated that chronic heart failure is associated with a generalised impairment of endotheliumdependent vasodilation, which may contribute to the progression of ventricular and vascular remodelling in this syndrome (Mendes Ribeiro et al. 2001).

\section{L-ARGININE - NITRIC OXIDE PATHWAY}

In 1980, Furchgott et al. (1980) first reported that endothelial cells release an endothelium-derived relaxing factor (EDRF). In 1987, this molecule was identified as being NO [21, 22], a labile gas that can diffuse readily across membranes and with a half-life ranging from 2 to $30 \mathrm{~s}$. NO can be reduced by the presence of molecular oxygen $\left(\mathrm{O}_{2}\right)$, superoxide anions $\left(\mathrm{O}_{2}^{-\bullet}\right)$ and heme proteins [23-25]. In mammalian cells, $\mathrm{NO}$ is synthesized from the terminal guanidino nitrogen atoms of L-arginine, a cationic amino acid, by NO synthases (NOS) (Fig. 1). This reaction involves two monooxygenation steps requiring $\mathrm{O}_{2}$ and NADPH: an initial hydroxylation of L-arginine to generate N-hydroxy-Larginine, followed by oxidation which leads to the formation of $\mathrm{NO}$ and L-citrulline [26, 27].

To date, three different isoforms of NOS have been identified: type I or neuronal (nNOS), type II or inducible (iNOS) and type III or endothelial (eNOS) [9, 26]. The isoforms nNOS and eNOS are constitutive and their activities are regulated by intracellular free calcium and the calcium-binding protein calmodulin, whereas the iNOS is calcium independent. Despite the well established role of the three NOS isoforms, recent evidence support the idea of NO production via the mitochondrial membrane in different cell types such as liver, kidney and cardiac cells [28-31]. This isoform is known as mitochondrial NOS (mtNOS) and it is

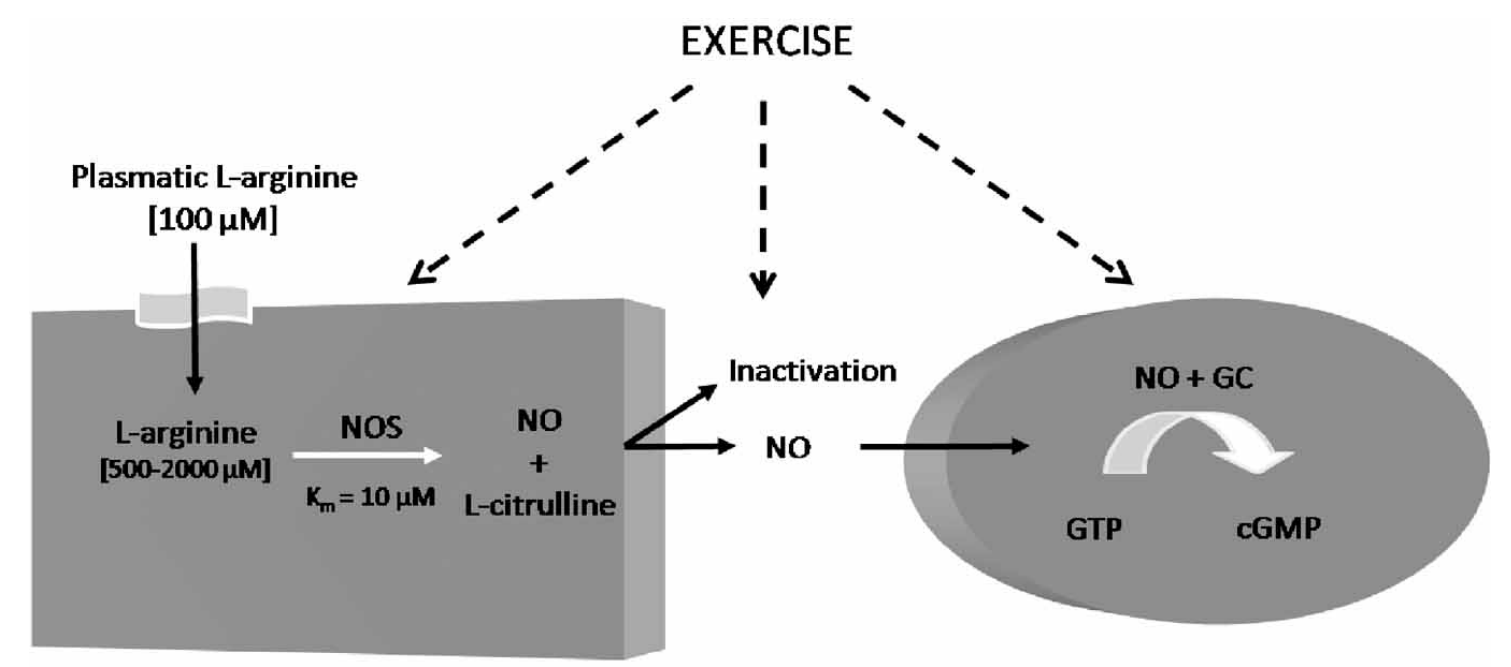

Generator Cell

Target Cell

Fig. (1). L-Arginine Nitric Oxide Pathway. GC: guanylyl cyclase; cGMP: cyclic guanosine monophosphate; NO: Nitric oxide; NOS: Nitric oxide; synthase. 
still unclear if mtNOS is a new isoform of NOS or a splicing of nNOS [30,32,33].

Approximately $10 \mathrm{nM}$ of $\mathrm{NO}$ is needed to activate guanylyl cyclase (GC)-coupled receptors leading to cGMP accumulation in vascular smooth muscle cells [34, 35]. Studies in vivo suggested that GC will display a dual regulation by NO: long-lasting tonic activity due to persistent occupation by NO of the heme binding site and phasic activity due to engagement of another unidentified site [34]. The cGMP influences a number of vascular cell types and regulates vasomotor tone, endothelial permeability, cell growth and differentiation, as well as platelet and blood cell interactions [36]. Moreover, cGMP increases the expression of methylarginine dimethylamino-hydrolase (DDAH), an enzyme that metabolizes asymmetric dimethylarginine, $\mathrm{N}(\mathrm{G})$-dimethyl-L-arginine (ADMA) and $\mathrm{N}(\mathrm{G})$ monomethyl-L-arginine (L-NMMA), which are competitive endogenous inhibitors of NOS. It is possible that this effect serves to maintain $\mathrm{NO}$ levels in the endothelial environment [37].

L-arginine is considered a semi-essential amino acid in most adult mammals, but under certain conditions where the synthesis of L-arginine is decreased and/or its catabolism is increased, L-arginine becomes an essential amino acid [38]. In humans, the kidney and dietary intake are responsible for maintaining normal plasma levels of this amino acid, which range from 80 to $100 \mu \mathrm{M}$ in healthy patients $[39,40]$.

Membrane transport of L-arginine in mammalian cells is predominantly mediated via four transport systems: $\mathrm{y}^{+}, \mathrm{y}^{+} \mathrm{L}$, $\mathrm{B}^{\mathrm{o},+}$ and $\mathrm{b}^{\mathrm{o},+}$, with different kinetic patterns $[41,42]$. Several studies have demonstrated that L-arginine transport is rate limiting for generating NO by endothelial cells activated macrophages, platelets, endothelium and brain astrocytes, despite the fact that the intracellular concentration of Larginine remains well above $K_{m}$ values for NOS [43-47]. This special feature is known as the "L-arginine paradox" $[48,49]$. There are also studies suggesting the participation of citrulline-arginine recycling via the citrulline-NO cycle in high-output production of NO in activated microglial cells and in endothelial cells [50].

\section{L-ARGININE - NO PATHWAY IN CHRONIC HEART FAILURE}

There is general consensus that the basic disturbance underlying the pathology of heart failure is the loss of functioning, necrotic or apoptotic myocardial cells, resulting in an inadequate blood flow to peripheral tissues [51, 52]. In this syndrome, a cascade of neurohormonal and hemodynamic mechanisms, such as activation of the sympathetic system and renin-angiotensin-aldosterone system, are activated to preserve cardiac function. However, prolonged activation of these pathways is deleterious and is responsible for the development of chronic heart failure [51, 53]. Furthermore, increased oxidative stress and the presence of an inflammatory status may contribute further to cardiac remodelling and vascular dysfunction observed in this illness [54-57]. CHF is thus a very complex syndrome characterised by a myriad of cellular and systemic alterations. There is accumulating evidence that the L-arginine-NO pathway has an important role in the pathophysiology of this disorder [6].
According to several studies, endothelial dysfunction could result from decreased release or enhanced inactivation of NO by increased oxidative stress found in CHF [3]. Therefore, disturbances of the L-arginine-NO pathway reported in CHF may have an important role in the pathogenesis of this syndrome (Table 1). Decreased activity of the L-arginine-NO pathway is suggested by reduced urinary excretion of nitrates in heart failure patients at rest and during exercise after infusion of L- $\left[{ }^{15} \mathrm{~N}\right]$-arginine and by decreased eNOS expression and NO synthesis in the aortic endothelium from experimental rodent models of heart failure [58-61]. Clinical and animal models of CHF have reported increased plasma levels of ADMA, which would inhibit NO production and lead to decreased endotheliumdependent relaxation [62-65]. Moreover, elevated levels of ADMA have been proposed as a predictor of adverse cardiovascular outcomes in patients with heart failure [66]. In contrast, several clinical studies have demonstrated that patients with heart failure exhibit an increased responsiveness to inhibitors of NO synthesis and elevated plasma levels of stable NO breakdown products [67-70], suggesting that NO synthesis is increased rather than decreased.

Furthermore, an activation of L-arginine uptake in erythrocytes and aorta were found in patients and in rodent models of heart failure, respectively [71, 72]. According to these findings, it is possible that the increment in L-arginine transport could represent an adaptive response to increase Larginine availability for a putative increase in basal NO production in heart failure. On the other hand, Kaye et al. [69] have shown an impairment of L-arginine uptake associated with the reduction of CAT-1 expression in myocardial cells from chronic heart failure patients.

Our group has detected the presence of a disturbance in the plasma amino acid profile in CHF, with concentrations of most amino acids lower compared to healthy age-matched controls [72]. The plasma levels of L-arginine in heart failure were reduced by $50 \%$ of control values (Table 1). In this context, increased L-arginine transport observed in erythrocytes from CHF patients may reflect a widespread compensatory response to the decreased plasma L-arginine to sustain elevated production of NO. We have also report that plasma levels of L-NMMA are elevated in CHF patients [72].

The presence of nNOS, eNOS and iNOS have been detected in myocardium [73]. Increasing evidence indicates that expression and activity of iNOS is increased in different tissues and cells in heart failure [71, 74, 75]. In contrast, conflicting data exist with regard to eNOS expression and activity [73]. nNOS seems also to be involved in the pathogenesis of heart failure, and according to one study, myocardial cells from heart failure patients have an increased expression and activity of nNOS [76]. The reasons underlying conflicting findings in the L-arginine-NO pathway in chronic heart failure are unknown and may reflect the diverse causes and severity of this disease.

\section{EFFECTS OF EXERCISE IN HEART FAILURE PATIENTS}

It is well known that exercise training leads to beneficial adaptations in patients with heart failure, including an improvement in symptoms and quality of life, reduction of 
Table 1. Modulation of the L-Arginine-NO Pathway in Chronic Heart Failure

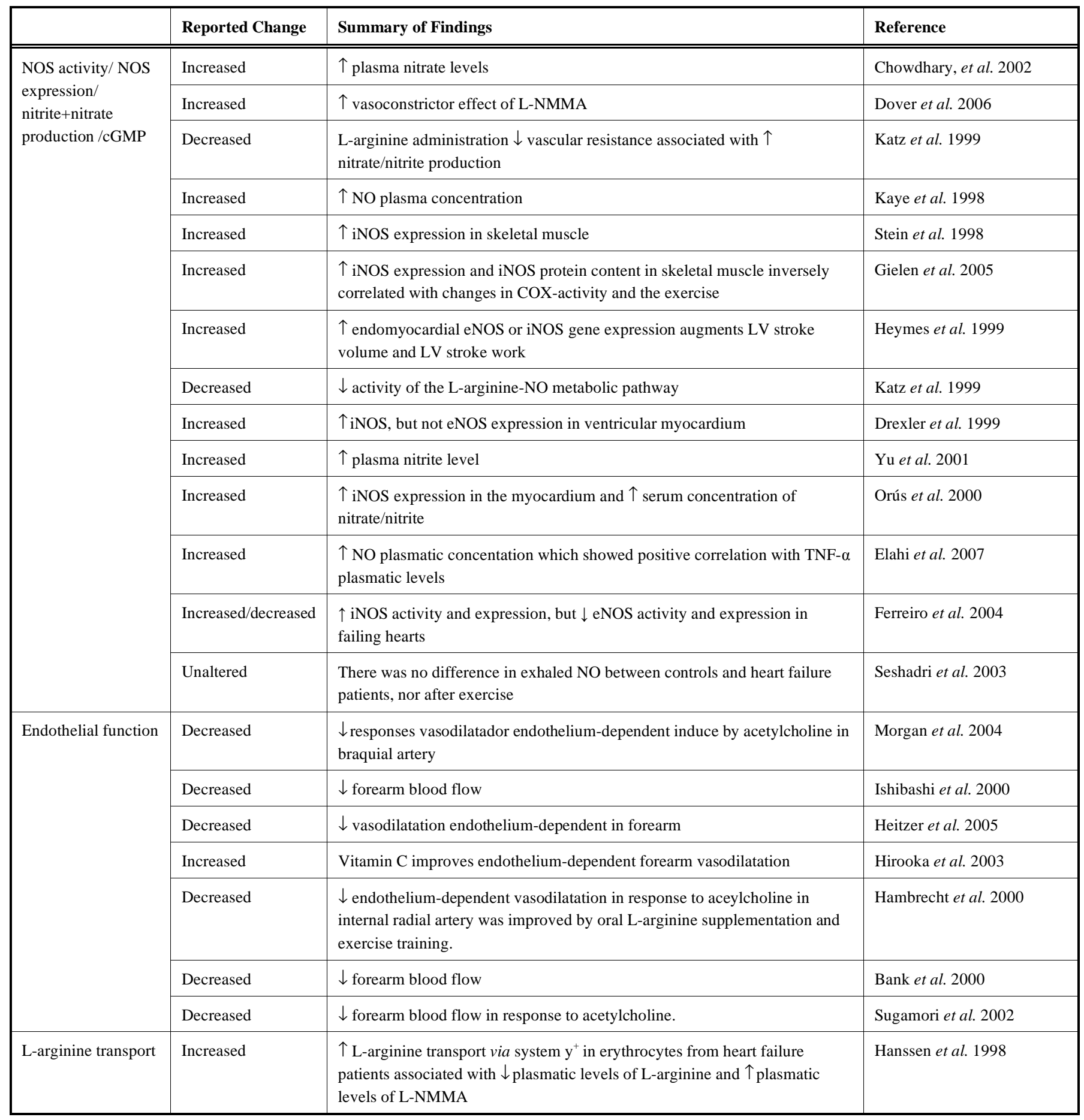

L-NMMA, $\mathrm{N}^{\mathrm{G}}$-monomethyl L-arginine; NO, nitric oxide; NOS, nitric oxide synthase; iNOS, inducible nitric oxide synthase; eNOS, endothelial nitric oxide synthase; PBMCs, peripheral blood mononuclear cells; COX, cytochrome e oxidase.

fatigue and dyspnea, and enhancement of exercise tolerance. Thus, exercise training is strongly recommended by the American Heart Association [14] and the European Society of Cardiology [2], as part of the treatment for mild to moderate heart failure. These patients usually have a very low exercise capacity with $\mathrm{VO}_{2}$ peak levels between 12 to 15 $\mathrm{mL} \cdot \mathrm{kg}^{-1} \cdot \mathrm{min}^{-1}$, approximately half of that observed in healthy individuals matched by age and gender [77]. Improving exercise tolerance, and consequently $\mathrm{VO}_{2 \text { peak }}$, is important for two major reasons: (1) the minimum threshold for independent living is 18 and $15 \mathrm{~mL} \cdot \mathrm{kg}^{-1} \cdot \mathrm{min}^{-1}$ for elderly men and women, respectively [78]; and (2) heart failure patients with $\mathrm{VO}_{2 \text { peak }}$ lower than $14 \mathrm{~mL} \cdot \mathrm{kg}^{-1} \cdot \mathrm{min}^{-1}$ are candidates for heart transplantation [79].

There is an extensive body of knowledge regarding the positive effects of exercise on functional capacity, demonstrated by an increase in $\mathrm{VO}_{2 \text { peak }}$, an improvement in the New York Heart Association functional classification, quality of 
life and functional autonomy [80]. The benefits are not restricted to the functional aspect, but extend to a lower mortality rate and to hospital readmission [81]. It is worth noting, however, that more conclusive data will be available after the termination of the trial Heart Failure: A Controlled Trial Investigating Outcomes of Exercise Training (HFACTION). This is the largest trial investigating the effects of exercise on HF patients and has been conducted since 2002 in more than 50 U.S. and Canadian hospitals involving 3000 patients.

The causes of exercise intolerance and the precise mechanisms for the beneficial effects of exercise in heart failure are still being extensively discussed. It has been suggested that central (related to the heart) and peripheral (related to the muscle and the vasculature) factors, in addition to neurohormonal modifications, can contribute to exercise intolerance [82]. An in-depth review about the central, metabolic, and neurohormonal adaptations associated with exercise training is beyond the scope of this review.

Exercise has also been shown to improve some alterations in neuro-hormonal overactivity found in CHF. A reduction in norepinephrine spillover, enhancement in the vagal high frequency component of heart rate variability, and a decrease in the sympathetically mediated low-frequency oscillation have been demonstrated. [83, 84]. Although controversial, it is possible that these effects of exercise are secondary to skeletal muscle or peripheral vascular training improvement [83-85]. Recently, consistent data has suggested that reduction in sympathetic nerve activity and improvement in baroreflex function in CHF after exercise are due to the concomitant reduction in angiotensin II and angiotensin receptors in the central nervous system [86].

\subsection{Vascular Adaptations to Exercise in Heart Failure Patients: Role of L-Arginine-NO Pathway}

Exercise intolerance can also result from the systemic vasoconstriction and diminished peripheral perfusion commonly seen in heart failure. In this context, the endothelium, and especially NO, constitute central figures in vasomotor tone and perfusion regulation [87]. It has been consistently demonstrated that exercise training restores endothelium function in $\mathrm{CHF}$ patients. An increase in the brachial artery diameter [88] or in forearm blood flow [89] was observed after infusion of acetylcholine, but not by nitroglycerine or sodium nitroprussiate, indicating an improvement in endothelium-dependent and nonindependent vasodilation. Flow-dependent vasodilation is also increased after exercise training [90]. These changes were observed after at least 4 weeks of different exercise modes, including aerobic training on a cycle ergometer [87], local muscular endurance training (handgrip) [89] and circuit training involving resistance plus aerobic training [91]. Table 2 presents a summary of the trials involving exercise and vascular changes in heart failure patients.

Although it is clear that exercise training enhances vascular endothelial function and particularly NO-mediated vasodilation, the molecular basis for this improvement has still not been completely elucidated. The preponderance of data suggests that a great part of the beneficial effects on vascular structure and reactivity are due to exercise-induced increases in endothelial shear stress. Exercise, by means of its transient increase in blood flow, affects the two forces acting on an artery. One is perpendicular to the wall and represents blood pressure, and the other acts parallel to the wall creating a frictional force at the surface of the endothelium, the so-called shear stress. Intra-arterial pressure seems to have little effect on endothelial control of vasoactivity; in contrast the principal regulator of arterial diameter is shear stress, mainly through NO release.

Acutely, shear stress mediates a biphasic production of NO with an initial rapid rise at the onset of flow, followed by a sustained increased level of production. The activation of eNOS occurs mainly through two mechanisms: calcium/ calmodulin, which dissociates eNOS from caveolin-1 [92], and phosphorylation of eNOS-S ${ }^{1179}$ and eNOS-S ${ }^{635}$ by protein kinase $\mathrm{A}$, protein kinase $\mathrm{B}$, and phosphoinositide-3kinase $[93,94]$. Chronically, shear stress induces an increase in the eNOS expression level and cGMP production [95]. Supporting these studies in vitro, it was demonstrated that exercise training caused an increase in eNOS expression in aortic endothelial cells [96] and prevented its decrease in the exercising muscle [97] of heart failure animal models. Recently, shear stress has also been shown to augment tetrahydrobiopterin $\left(\mathrm{BH}_{4}\right)$ levels and enzymatic activity of GTP cyclohydrolase-1, the first step of $\mathrm{BH}_{4}$ biosynthesis, in human endothelial cells [98].

Although it is clear from studies in vitro and animal models in vivo that shear stress and physical exercise affect eNOS expression and $\mathrm{BH}_{4}$ levels, there is limited evidence from human studies involving $\mathrm{CHF}$ patients. To our knowledge, only one study has investigated this issue in humans and no changes in the steady-state transcription levels of eNOS, angiotensin converting enzyme, or prostacyclin synthase were detected in samples of vastus lateralis muscle after 12 weeks of moderate intensity endurance training [99]. On the other hand, the same study showed that exercise caused an $100 \%$ increase in gene expression of the antioxidant enzymes cupper/zinc superoxide dismutase (CuZnSOD) and glutathione peroxidise-1 $(\mathrm{GPx}-1)$ [99]. Thus, the positive effects of exercise on the vasculature may be due to reduced oxidative stress rather than an increase in eNOS expression, leading to an increase in NO bioavailability. However, it does not seem to be a consistent finding, since Linke et al. reported that mRNA levels and protein expression of MnSOD, CuZnSOD, GPx-1 and catalase (Cat) were unaltered after 6 months of training in samples of the vastus lateralis muscle of chronic heart failure patients [100]. These opposite findings might be due to different methods used to normalize mRNA transcripts of GPx-1 and CuZnSOD.

It is important to remember that further studies are needed to confirm these findings and also to investigate exercise induced changes in the expression and activity of eNOS and antioxidant enzymes in the endothelium and other cell types. Exercise may also affect another step involved in NO synthesis from L-arginine. After 8 weeks of endurance training at 50 to $60 \%$ of maximum heart rate, L-arginine transport, measured by the clearance rate of $\mathrm{L}-\left[{ }^{3} \mathrm{H}\right]$-arginine, increased in heart failure patients associated with an improvement in endothelial function [101]. 
Table 2 Effects of Exercise in Heart Failure Patients

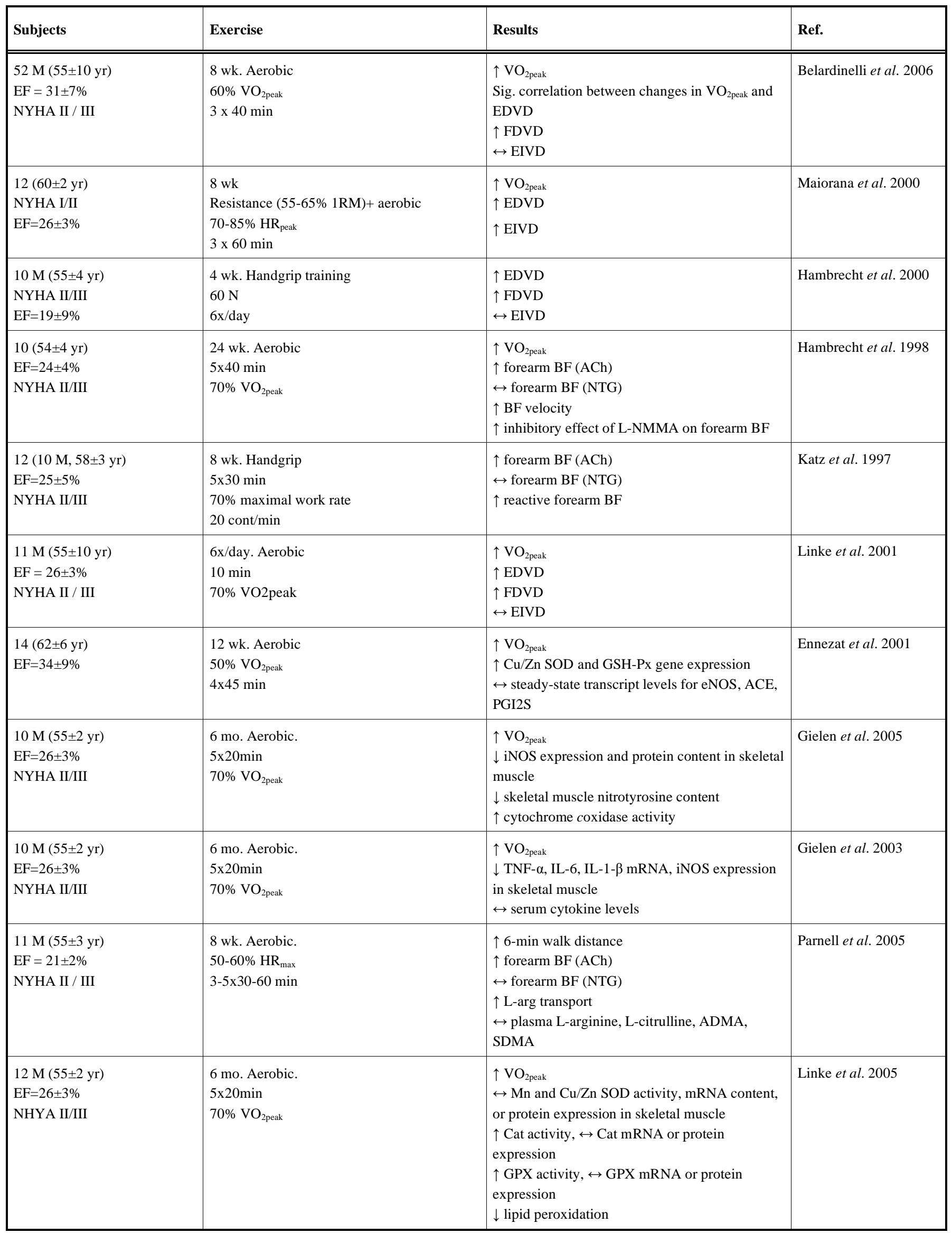


(Table 2). Contd.....

\begin{tabular}{|c|c|c|c|}
\hline Subjects & Exercise & Results & Ref. \\
\hline $\begin{array}{l}24(55 \pm 2 y r) \\
\text { EF: } 23 \pm 1 \% \\
\text { NYHA II/III }\end{array}$ & $\begin{array}{l}12 \text { wk. Aerobic. } \\
60-80 \% \mathrm{HR}_{\max } \\
5 \times 30 \mathrm{~min}\end{array}$ & $\begin{array}{l}\uparrow \mathrm{VO}_{2 \text { peak }} \\
\downarrow \text { serum TNF- } \alpha, \text { sTNFR1, sTNFR2, IL-6. sIL- } \\
6 \mathrm{R}, \text { sFas, sFasL }\end{array}$ & $\begin{array}{l}\text { Adamopoulos et al. } \\
2002\end{array}$ \\
\hline $\begin{array}{l}23(27-78 \mathrm{yr}) \\
\text { EF: } 11-45 \% \\
\text { NYHA I-IV }\end{array}$ & $\begin{array}{l}4 \mathrm{mo} .3 \mathrm{x} / \mathrm{wk} \\
\text { Aerobic }+\mathrm{RT} \\
\text { Aerobic: } 20 \mathrm{~min} 90 \% \mathrm{VT} \\
\text { RT: } 2 \times 10 \text { reps } 50 \% 1 \mathrm{RM}\end{array}$ & $\begin{array}{l}\uparrow \mathrm{VO}_{2 \text { peak }} \\
\uparrow \mathrm{NYHA} \text { class } \\
\leftrightarrow \text { serum TNF- } \alpha, \mathrm{IL}-6 \\
\downarrow \text { sTNFR } 1, \text { sTNFR2 (DAC) }\end{array}$ & Conraads et al. 2002 \\
\hline $\begin{array}{l}18(54 \pm 9 \mathrm{yr}) \\
\text { NHYA } 2.2 \pm 0.7\end{array}$ & $\begin{array}{l}8 \text { wk. Aerobic. } \\
5 \times 20 \text { min } \\
70-80 \% \text { HRmax } \\
\text { Calistenics }\end{array}$ & $\begin{array}{l}\uparrow \mathrm{VO}_{2 \text { peak }} \\
\leftrightarrow \text { plasma TNF- } \alpha \text {, TNF-R } 1 \text { and } 2, \text { IL-6, e- } \\
\text { selectin, sICAM, sCD14 }\end{array}$ & Niebauer et al. 2005 \\
\hline
\end{tabular}

ADMA = asymmetric dimethylarginine; $\mathrm{CAD}=$ coronary arterial disease; $\mathrm{M}=$ men; $\mathrm{EF}=$ ejection fraction; NYHA = New York Heart Association; EDVD = endothelium dependent vasodilation; FDVD = flow dependent vasodilation; EIVD = endothelium independent vasodilation; $\mathrm{BF}=\mathrm{blood}$ flow; $\mathrm{ACh}=$ acetylcoline; $\mathrm{NTG}=$ nitroglycerine; $\mathrm{L}-\mathrm{NMMA}=N^{\mathrm{G}}$ monomethyl-L-arginine; SOD = superoxide dismutase; GSH-Px = glutathione-peroxidase; eNOS = endothelial nitric oxide synthase; iNOS = inducible nitric oxide synthase; ACE = angiotensin-converting enzyme; $\mathrm{PGI}_{2}=$ prostacyclin; cont $=$ contraction; wk = week.

In addition to its effect on vasomotion, $\mathrm{NO}$ is known to antagonize key processes involved in thrombus formation, including monocyte adherence and chemotaxis, platelet adhesion and aggregation, and vascular smooth cell proliferation (Moncada et al., 2006; Brunini et al., 2007). Therefore, another potential favourable effect of exercise, though not confirmed by long-term studies, would be a reduction in the incidence of thrombotic events, which is higher in heart failure patients than in the general population. In healthy individuals, a reduction in platelet aggregation induced by oxidized LDL after 8 weeks of aerobic training was shown [102].

\subsection{Exercise and Inflammation in Heart Failure}

There is convincing evidence that inflammatory mediators play an important role in skeletal muscle wasting and fatigue in heart failure [103]. Among the cytokines, TNF particularly has been shown to provoke net nitrogen loss and catabolism when administered to experimental animals [104]. In skeletal muscle biopsies from heart failure patients, the cytokines interleukin IL1- $\beta$ and TNF- $\alpha$ can induce a pathological increase in iNOS in skeletal muscle via activation of nuclear factor kappa B (NFkB) [105]. High iNOS-derived NO concentrations in skeletal muscle may inhibit key aerobic enzymes such as cytochrome $c$ oxidase, impairing cellular respiration and causing structural damage to the mitochondria [106].

Despite all of the positive actions of NO that have been highlighted, overproduction of NO can lead to serious cytotoxic effects in the skeletal muscle and even the heart [107]. Long-term aerobic training causes a reduction in the inflammatory state of skeletal muscle, as evidenced by a diminished expression of TNF- $\alpha$, IL-6 and IL-1-beta mRNA expression [108]. Consequently, there is a reduction in iNOS expression and protein nitrotyrosine content, a marker of peroxynitrite formation from $\mathrm{NO}$ and superoxide radical, in exercised skeletal muscle from heart failure patients [109]. These findings were inversely associated with an increase in cytocrome $c$ oxidase activity, reflecting an improvement in muscular oxidative metabolism and increased $\mathrm{VO}_{2 \text { peak }}$. Except for one paper published by Adamopoulos et al. [110], serum concentrations of cytokines and their receptors do not seem to decrease after physical training [109, 111, 112], suggesting that changes in local cytokine expression occur earlier than in the circulating system.

Plasma levels of cytokines, particularly TNF- $\alpha$, IL-1 and IL-6, are elevated in CHF patients and may play a role in the genesis and progression of heart failure [113-117]. The increase in circulating concentrations of TNF- $\alpha$ and IL-6 correlated directly with the severity of the disease and with death and inversely with exercise tolerance in CHF [117120]. At the cardiac level, the overexpression of cytokines, induced by a variety of stressors, promotes contractile dysfunction, impaired $\beta$ adrenergic receptor sensitivity, alterations in vascular endothelium and recruitment of additional circulating inflamed cells in injured myocardium $[114,121]$. Moreover, a long-term presence of these inflammatory mediators results in myocyte phenotype transition and activation of matrix metalloproteinases, which modifies the interstitial matrix, further increasing the remodeling process [122]. Studies in vivo also suggest that the death of apoptotic myocytes after sustained TNF signaling is a consequence the depletion of one or more antiapoptotic cytoprotective proteins [123].

Exercise training, particularly endurance exercise, has been shown to promote a decrease in oxidative stress and inflammation which can interfere in NOS activity and expression. Nevertheless, it is important to highlight that the benefits of exercise on vascular tone and muscle perfusion through its effects on NO bioavailability can explain only part of the benefits conferred by exercise training. Vascular tone can also be influenced by sympathetic activity and hormonal factors, and both can also be positively affected by regular exercise.

\section{CONCLUSION}

In this review, we critically examined the mechanisms underlying chronic heart failure and potential clinical benefits of exercise. The endothelial dysfunction present in CHF, partly reversed by exercise, is involved in widespread vasoconstriction in heart failure. It seems that interfering with L-arginine-NO pathway, inflammation and free radical 
metabolism may be useful adaptations to training in $\mathrm{CHF}$ patients.

\section{ACKNOWLEDGEMENT}

We acknowledge financial support from FAPERJ and PQ-CNPq.

\section{REFERENCES}

[1] Mann, D.L.; Bristow, M.R. Mechanisms and models in heart failure: the biomechanical model and beyond. Circulation, 2005, 111, 2837-2849.

[2] Dickstein, K.; Cohen-Solal, A.; Filippatos, G.; McMurray, J. J.; Ponikowski, P.; Poole-Wilson, P. A.; Stromberg, A.; van Veldhuisen, D. J.; Atar, D.; Hoes, A. W.; Keren, A.; Mebazaa, A.; Nieminen, M.; Priori, S. G.; Swedberg, K.; Vahanian, A.; Camm, J.; De Caterina, R.; Dean, V.; Funck-Brentano, C.; Hellemans, I.; Kristensen, S. D.; McGregor, K.; Sechtem, U.; Silber, S.; Tendera, M.; Widimsky, P.; Zamorano, J. L.; Auricchio, A.; Bax, J.; Bohm, M.; Corra, U.; Della Bella, P.; Elliott, P. M.; Follath, F.; Gheorghiade, M.; Hasin, Y.; Hernborg, A.; Jaarsma, T.; Komajda, M.; Kornowski, R.; Piepoli, M.; Prendergast, B.; Tavazzi, L.; Vachiery, J. L.; Verheugt, F. W.; Zannad, F. ESC Guidelines for the diagnosis and treatment of acute and chronic heart failure 2008: The Task Force for the Diagnosis and Treatment of Acute and Chronic Heart Failure 2008 of the European Society of Cardiology. Developed in collaboration with the Heart Failure Association of the ESC (HFA) and endorsed by the European Society of Intensive Care Medicine (ESICM). Eur. Heart J., 2008, 10, 933-989.

[3] Landmesser, U.; Drexler, H. The clinical significance of endothelial dysfunction. Curr. Opin. Cardiol., 2005, 20, 547-551.

[4] Carville, C.; Adnot, S.; Sediame, S.; Benacerraf, S.; Castaigne, A.; Calvo, F.; de Cremou, P.; Dubois-Rande, J. L. Relation between impairment in nitric oxide pathway and clinical status in patients with congestive heart failure. J. Cardiovasc. Pharmacol., 1998, 32, 562-570.

[5] Stewart, D.J. Nitric oxide puzzles and paradoxes in heart failure: how to fit the pieces together? Clin. Sci. Lond., 1998, 94, 3-4.

[6] Mendes Ribeiro, A. C.; Brunini, T. M.; Ellory, J. C.; Mann, G. E. Abnormalities in L-arginine transport and nitric oxide biosynthesis in chronic renal and heart failure. Cardiovasc. Res., 2001, 49, 697712.

[7] Palmer, R.M.; Rees, D.D.; Ashton, D.S.; Moncada, S. L-arginine is the physiological precursor for the formation of nitric oxide in endothelium-dependent relaxation. Biochem. Biophys. Res. Commun., 1988, 153, 1251-1256.

[8] Bredt, D. S.; Hwang, P. M.; Glatt, C. E.; Lowenstein, C.; Reed, R. R.; Snyder, S. H. Cloned and expressed nitric oxide synthase structurally resembles cytochrome P-450 reductase. Nature, 1991, $351,714-718$.

[9] Moncada, S. Adventures in vascular biology: a tale of two mediators. Philos. Trans. R. Soc. Lond. B. Biol. Sci., 2006, 361, 735-759.

[10] Ignarro, L. J. Heme-dependent activation of guanylate cyclase by nitric oxide: a novel signal transduction mechanism. Blood Vessels, 1991, 28, 67-73.

[11] Rush, J. W.; Denniss, S. G.; Graham, D. A. Vascular nitric oxide and oxidative stress: determinants of endothelial adaptations to cardiovascular disease and to physical activity. Can. J. Appl. Physiol., 2005, 30, 442-474.

[12] Piepoli, M. F. Exercise training in heart failure. Curr. Cardiol. Rep., 2005, 7, 216-222.

[13] Jessup, M.; Brozena, S., Heart failure. N. Engl. J. Med., 2003, 348, 2007-2018.

[14] Hunt, S.A.; Abraham, W.T.; Chin, M.H.; Feldman, A.M.; Francis, G.S.; Ganiats, T. G.; Jessup, M.; Konstam, M.A.; Mancini, D.M.; Michl, K.; Oates, J.A.; Rahko, P.S.; Silver, M.A.; Stevenson, L.W.; Yancy, C.W.; Antman, E.M.; Smith, S.C., Jr.; Adams, C.D.; Anderson, J.L.; Faxon, D.P.; Fuster, V.; Halperin, J.L.; Hiratzka, L.F.; Jacobs, A. K.; Nishimura, R.; Ornato, J.P.; Page, R.L.; Riegel, B.; American College of C.; American Heart Association Task Force on Practice, G.; American College of Chest, P.; International Society for, H.; Lung, T.; Heart Rhythm, S., ACC/AHA 2005 Guideline Update for the Diagnosis and Management of Chronic Heart Failure in the Adult: a report of the American College of
Cardiology/American Heart Association Task Force on Practice Guidelines (Writing Committee to Update the 2001 Guidelines for the Evaluation and Management of Heart Failure): developed in collaboration with the American College of Chest Physicians and the International Society for Heart and Lung Transplantation: endorsed by the Heart Rhythm Society. Circulation, 2005, 112, e154-235.

[15] Francis, G. S.; Tang, W.H. Pathophysiology of congestive heart failure. Rev. Cardiovasc. Med., 2003, 4 (Suppl 2), S14-20.

[16] Katz, A.M. Heart failure: a hemodynamic disorder complicated by maladaptive proliferative responses. J. Cell Mol. Med., 2003, 7, 110 .

[17] Anand, I.S. Pathogenesis of salt and water retention in the congestive heart failure syndrome. In The heart failure, Philip Poole-Wilson, Ed.; Churchill-Livingstone: London, 1997; pp. 155171.

[18] Ferreira, M.E. Insuficiência cardíaca, 1st ed.; Rubio: Rio de Janeiro, 2007.

[19] Eichhorn, E.J.; Bristow, M.R. Medical therapy can improve the biological properties of the chronically failing heart. A new era in the treatment of heart failure. Circulation, 1996, 94, 2285-2296.

[20] Sutton, M.G.; Sharpe, N. Left ventricular remodeling after myocardial infarction: pathophysiology and therapy. Circulation, 2000, 101, 2981-2988.

[21] Ignarro, L.J.; Buga, G.M.; Wood, K.S.; Byrns, R.E.; Chaudhuri, G. Endothelium-derived relaxing factor produced and released from artery and vein is nitric oxide. Proc. Natl. Acad. Sci. USA, 1987, 84, 9265-9269.

[22] Moncada, S.; Palmer, R.M.; Higgs, E.A. Biosynthesis of nitric oxide from L-arginine. A pathway for the regulation of cell function and communication. Biochem. Pharmacol., 1989, 38, 1709-1715.

[23] Marletta, M.A. Nitric oxide synthase: aspects concerning structure and catalysis. Cell, 1994, 78, 927-930.

[24] Archer, S. Measurement of nitric oxide in biological models. FASEB J. 1993, 7, 349-360.

[25] Bryan, N.S.; Grisham, M.B. Methods to detect nitric oxide and its metabolites in biological samples. Free Radic. Biol. Med., 2007, 43, 645-657.

[26] Gross, R.; Roye, M.; Manteghetti, M.; Broca, C.; Hillaire-Buys, D.; Masiello, P.; Ribes, G. Mechanisms involved in the effect of nitric oxide synthase inhibition on L-arginine-induced insulin secretion. Br. J. Pharmacol., 1997, 120, 495-501.

[27] Dudzinski, D.M.; Igarashi, J.; Greif, D.; Michel, T. The regulation and pharmacology of endothelial nitric oxide synthase. Annu. Rev. Pharmacol. Toxicol., 2006, 46, 235-276.

[28] Ghafourifar, P.; Richter, C. Nitric oxide synthase activity in mitochondria. FEBS Lett., 1997, 418, 291-296.

[29] Kanai, A.J.; Pearce, L.L.; Clemens, P.R.; Birder, L.A.; VanBibber, M.M.; Choi, S. Y.; de Groat, W.C.; Peterson, J. Identification of a neuronal nitric oxide synthase in isolated cardiac mitochondria using electrochemical detection. Proc. Natl. Acad. Sci. USA, 2001, 98, 14126-14131.

[30] Valdez, L.B.; Boveris, A. Mitochondrial nitric oxide synthase, a voltage-dependent enzyme, is responsible for nitric oxide diffusion to cytosol. Front. Biosci., 2007, 12, 1210-1219.

[31] Boveris, A.; Valdez, L.B.; Alvarez, S.; Zaobornyj, T.; Boveris, A.D.; Navarro, A. Kidney mitochondrial nitric oxide synthase. Antioxid. Redox. Signal., 2003, 5, 265-271.

[32] Elfering, S.L.; Sarkela, T.M.; Giulivi, C. Biochemistry of mitochondrial nitric-oxide synthase. J. Biol. Chem., 2002, 277, 38079-38086.

[33] Valdez, L.B.; Zaobornyj, T.; Boveris, A. Mitochondrial metabolic states and membrane potential modulate mtNOS activity. Biochim. Biophys. Acta, 2006, 1757, 166-172.

[34] Roy, B.; Garthwaite, J. Nitric oxide activation of guanylyl cyclase in cells revisited. Proc. Natl. Acad. Sci. USA, 2006, 103, 1218512190.

[35] Boerrigter, G.; Lapp, H.; Burnett, J.C. Modulation of cGMP in heart failure: a new therapeutic paradigm. Handb. Exp. Pharmacol., 2009, 485-506.

[36] Simonsen, U.; Rodriguez-Rodriguez, R.; Dalsgaard, T.; Buus, N. H.; Stankevicius, E. Novel approaches to improving endotheliumdependent nitric oxide-mediated vasodilatation. Pharmacol. Rep. 2009, 61, 105-115. 
[37] Sakurada, M.; Shichiri, M.; Imamura, M.; Azuma, H.; Hirata, Y. Nitric oxide upregulates dimethylarginine dimethylaminohydrolase-2 via cyclic GMP induction in endothelial cells. Hypertension, 2008, 52, 903-909.

[38] Morris, S.M., Jr. Recent advances in arginine metabolism. Curr. Opin. Clin. Nutr. Metab. Care, 2004, 7, 45-51.

[39] Reyes, A.A.; Karl, I.E.; Yates, J.; Klahr, S. Low plasma and renal tissue levels of L-arginine in rats with obstructive nephropathy. Kidney Int., 1994, 45, 782-787.

[40] Mendes Ribeiro, A. C.; Brunini, T. M., L-Arginine transport in disease. Curr. Med. Chem. Cardiovasc. Hematol. Agents, 2004, 2, 123-131.

[41] Ignarro, L.J.; Napoli, C.; Loscalzo, J. Nitric oxide donors and cardiovascular agents modulating the bioactivity of nitric oxide: an overview. Circ. Res. 2002, 90, 21-28.

[42] Mann, G. E.; Yudilevich, D. L.; Sobrevia, L. Regulation of amino acid and glucose transporters in endothelial and smooth muscle cells. Physiol. Rev., 2003, 83, 183-252.

[43] Shibazaki, T.; Fujiwara, M.; Sato, H.; Fujiwara, K.; Abe, K.; Bannai, S. Relevance of the arginine transport activity to the nitric oxide synthesis in mouse peritoneal macrophages stimulated with bacterial lipopolysaccharide. Biochim. Biophys. Acta, 1996, 1311, $150-154$.

[44] Stevens, B.R.; Kakuda, D.K.; Yu, K.; Waters, M.; Vo, C.B.; Raizada, M.K. Induced nitric oxide synthesis is dependent on induced alternatively spliced CAT-2 encoding L-arginine transport in brain astrocytes. J. Biol. Chem., 1996, 271, 24017-24022.

[45] Bogle, R.G.; Baydoun, A.R.; Pearson, J.D.; Mann, G.E. Regulation of L-arginine transport and nitric oxide release in superfused porcine aortic endothelial cells. J. Physiol., 1996, 490(Pt 1), 229241.

[46] Mendes Ribeiro, A.C.; Brunini, T.M.; Yaqoob, M.; Aronson, J.K.; Mann, G.E.; Ellory, J.C. Identification of system $y+L$ as the highaffinity transporter for L-arginine in human platelets: up-regulation of L-arginine influx in uraemia. Pflugers Arch., 1999, 438, 573575 .

[47] Zani, B.G.; Bohlen, H.G. Transport of extracellular 1-arginine via cationic amino acid transporter is required during in vivo endothelial nitric oxide production. Am. J. Physiol. Heart Circ. Physiol., 2005, 289, H1381-1390.

[48] Wyatt, A.W.; Steinert, J.R.; Mann, G.E. Modulation of the Larginine/nitric oxide signalling pathway in vascular endothelial cells. Biochem. Soc. Symp., 2004, 143-156.

[49] Vukosavljevic, N.; Jaron, D.; Barbee, K.A.; Buerk, D.G. Quantifying the L-arginine paradox in vivo. Microvasc. Res., 2006, 71, 48-54.

[50] Kawahara, K.; Gotoh, T.; Oyadomari, S.; Kajizono, M.; Kuniyasu, A.; Ohsawa, K.; Imai, Y.; Kohsaka, S.; Nakayama, H.; Mori, M. Co-induction of argininosuccinate synthetase, cationic amino acid transporter-2, and nitric oxide synthase in activated murine microglial cells. Brain Res. Mol. Brain Res., 2001, 90, 165-173.

[51] Packer, M. Pathophysiology of chronic heart failure. Lancet, 1992, 340, 88-92.

[52] Tavernarakis, N. Cardiomyocyte necrosis: alternative mechanisms, effective interventions. Biochim. Biophys. Acta, 2007, 1773, 480482 .

[53] Mercadier, J. J. [Current pathophysiologic approaches to heart failure]. Presse Med., 2007, 36, 979-984.

[54] Grieve, D. J.; Shah, A. M. Oxidative stress in heart failure. More than just damage. Eur. Heart J. 2003, 24, 2161-2163.

[55] Hoare, G.S.; Birks, E.J.; Bowles, C.; Marczin, N.; Yacoub, M.H. In vitro endothelial cell activation and inflammatory responses in endstage heart failure. J. Appl. Physiol., 2006, 101, 1466-1473.

[56] Parodi, O.; De Maria, R.; Roubina, E. Redox state, oxidative stress and endothelial dysfunction in heart failure: the puzzle of nitratethiol interaction. J. Cardiovasc. Med., 2007, 8, 765-774.

[57] Vila, V.; Martinez-Sales, V.; Almenar, L.; Lazaro, I. S.; Villa, P.; Reganon, E. Inflammation, endothelial dysfunction and angiogenesis markers in chronic heart failure patients. Int. J. Cardiol., 2008, 130, 276-277.

[58] Comini, L.; Bachetti, T.; Gaia, G.; Pasini, E.; Agnoletti, L.; Pepi, P.; Ceconi, C.; Curello, S.; Ferrari, R., Aorta and skeletal muscle NO synthase expression in experimental heart failure. J. Mol. Cell Cardiol., 1996, 28, 2241-2248.

[59] Habib, F.M.; Springall, D.R.; Davies, G.J.; Oakley, C.M.; Yacoub, M.H.; Polak, J. M., Tumour necrosis factor and inducible nitric oxide synthase in dilated cardiomyopathy. Lancet, 1996, 347, 1151-1155.

[60] Katz, S.D.; Khan, T.; Zeballos, G.A.; Mathew, L.; Potharlanka, P.; Knecht, M.; Whelan, J. Decreased activity of the L-arginine-nitric oxide metabolic pathway in patients with congestive heart failure. Circulation, 1999, 99, 2113-2117.

[61] Wiemer, G.; Itter, G.; Malinski, T.; Linz, W. Decreased nitric oxide availability in normotensive and hypertensive rats with failing hearts after myocardial infarction. Hypertension, 2001, 38, 13671371.

[62] Saitoh, M.; Osanai, T.; Kamada, T.; Matsunaga, T.; Ishizaka, H.; Hanada, H.; Okumura, K. High plasma level of asymmetric dimethylarginine in patients with acutely exacerbated congestive heart failure: role in reduction of plasma nitric oxide level. Heart Vessels, 2003, 18, 177-182.

[63] Feng, Q.; Lu, X.; Fortin, A.J.; Pettersson, A.; Hedner, T.; Kline, R.L.; Arnold, J. M. Elevation of an endogenous inhibitor of nitric oxide synthesis in experimental congestive heart failure. Cardiovasc. Res., 1998, 37, 667-675.

[64] Usui, M.; Matsuoka, H.; Miyazaki, H.; Ueda, S.; Okuda, S.; Imaizumi, T. Increased endogenous nitric oxide synthase inhibitor in patients with congestive heart failure. Life Sci., 1998, 62, 24252430 .

[65] Kielstein, J.T.; Bode-Boger, S.M.; Klein, G.; Graf, S.; Haller, H.; Fliser, D. Endogenous nitric oxide synthase inhibitors and renal perfusion in patients with heart failure. Eur. J. Clin. Invest., 2003, 33, 370-375.

[66] Duckelmann, C.; Mittermayer, F.; Haider, D.G.; Altenberger, J.; Eichinger, J.; Wolzt, M. Asymmetric dimethylarginine enhances cardiovascular risk prediction in patients with chronic heart failure. Arterioscler. Thromb. Vasc. Biol., 2007, 27, 2037-2042.

[67] Dover, A.R.; Chia, S.; Ferguson, J.W.; Cruden, N.L.; Megson, I.L.; Fox, K.A.; Newby, D.E. Inducible nitric oxide synthase activity does not contribute to the maintenance of peripheral vascular tone in patients with heart failure. Clin. Sci. (Lond) 2006, 111, 275-280.

[68] Chowdhary, S.; Harrington, D.; Bonser, R.S.; Coote, J.H.; Townend, J.N. Chronotropic effects of nitric oxide in the denervated human heart. J. Physiol., 2002, 541, 645-651.

[69] Kaye, D.M.; Ahlers, B.A.; Autelitano, D.J.; Chin-Dusting, J.P. In vivo and in vitro evidence for impaired arginine transport in human heart failure. Circulation, 2000, 102, 2707-2712.

[70] Yu, C.M.; Fung, P.C.; Chan, G.; Lai, K.W.; Wang, Q.; Lau, C.P. Plasma nitric oxide level in heart failure secondary to left ventricular diastolic dysfunction. Am. J. Cardiol., 2001, 88, 867870 .

[71] Stathopulos, P.B.; Lu, X.; Shen, J.; Scott, J.A.; Hammond, J.R.; McCormack, D. G.; Arnold, J.M.; Feng, Q. Increased L-arginine uptake and inducible nitric oxide synthase activity in aortas of rats with heart failure. Am. J. Physiol. Heart Circ. Physiol. 2001, 280, H859-867.

[72] Hanssen, H.; Brunini, T.M.; Conway, M.; Banning, A.P.; Roberts, N.B.; Mann, G. E.; Ellory, J.C.; Mendes Ribeiro, A.C. Increased Larginine transport in human erythrocytes in chronic heart failure. Clin. Sci., 1998, 94, 43-48.

[73] Seddon, M.; Shah, A.M.; Casadei, B. Cardiomyocytes as effectors of nitric oxide signalling. Cardiovasc. Res., 2007, 75, 315-326.

[74] Gealekman, O.; Abassi, Z.; Rubinstein, I.; Winaver, J.; Binah, O. Role of myocardial inducible nitric oxide synthase in contractile dysfunction and beta-adrenergic hyporesponsiveness in rats with experimental volume-overload heart failure. Circulation, 2002, 105, 236-243.

[75] Ferreiro, C.R.; Chagas, A.C.; Carvalho, M.H.; Dantas, A.P.; Scavone, C.; Souza, L. C.; Buffolo, E.; da Luz, P.L. Expression of inducible nitric oxide synthase is increased in patients with heart failure due to ischemic disease. Braz. J. Med. Biol. Res., 2004, 37, 1313-1320.

[76] Damy, T.; Ratajczak, P.; Shah, A.M.; Camors, E.; Marty, I.; Hasenfuss, G.; Marotte, F.; Samuel, J.L.; Heymes, C. Increased neuronal nitric oxide synthase-derived NO production in the failing human heart. Lancet, 2004, 363, 1365-1367.

[77] Warburton, D.E.; Taylor, A.; Bredin, S.S.; Esch, B.T.; Scott, J.M.; Haykowsky, M. J. Central haemodynamics and peripheral muscle function during exercise in patients with chronic heart failure. Appl. Physiol. Nutr. Metab., 2007, 32, 318-331. 
[78] Paterson, D.H.; Govindasamy, D.; Vidmar, M.; Cunningham, D.A.; Koval, J.J. Longitudinal study of determinants of dependence in an elderly population. J. Am. Geriatr. Soc., 2004, 52, 1632-1638.

[79] Costanzo, M. R.; Augustine, S.; Bourge, R.; Bristow, M.; O'Connell, J. B.; Driscoll, D.; Rose, E. Selection and treatment of candidates for heart transplantation. A statement for health professionals from the Committee on Heart Failure and Cardiac Transplantation of the Council on Clinical Cardiology, American Heart Association. Circulation, 1995, 92, 3593-3612.

[80] Pina, I.L.; Apstein, C.S.; Balady, G.J.; Belardinelli, R.; Chaitman, B.R.; Duscha, B. D.; Fletcher, B.J.; Fleg, J.L.; Myers, J.N.; Sullivan, M.J. American Heart Association Committee on exercise, r.; prevention, Exercise and heart failure: A statement from the American Heart Association Committee on exercise, rehabilitation, and prevention. Circulation, 2003, 107, 1210-1225.

[81] Belardinelli, R.; Georgiou, D.; Cianci, G.; Purcaro, A. Randomized, controlled trial of long-term moderate exercise training in chronic heart failure: effects on functional capacity, quality of life, and clinical outcome. Circulation, 1999, 99, 11731182.

[82] Keteyian, S. J. Exercise rehabilitation in chronic heart failure. Coron. Artery Dis., 2006, 17, 233-237.

[83] Coats, A.J. A sympathetic heart and the art of dying. Eur. Heart J., 2001, 22, 1069-1071.

[84] Negrao, C.E.; Middlekauff, H.R. Adaptations in autonomic function during exercise training in heart failure. Heart Fail. Rev., 2008, 13, 51-60.

[85] Wallin, B. G.; Charkoudian, N. Sympathetic neural control of integrated cardiovascular function: insights from measurement of human sympathetic nerve activity. Muscle Nerve, 2007, 36, 595614 .

[86] Mousa, T. M.; Liu, D.; Cornish, K. G.; Zucker, I. H., Exercise training enhances baroreflex sensitivity by an angiotensin IIdependent mechanism in chronic heart failure. J. Appl. Physiol. 2008, 104, 616-624.

[87] Hambrecht, R.; Fiehn, E.; Weigl, C.; Gielen, S.; Hamann, C.; Kaiser, R.; Yu, J.; Adams, V.; Niebauer, J.; Schuler, G. Regular physical exercise corrects endothelial dysfunction and improves exercise capacity in patients with chronic heart failure. Circulation, 1998, 98, 2709-2715.

[88] Hambrecht, R.; Hilbrich, L.; Erbs, S.; Gielen, S.; Fiehn, E.; Schoene, N.; Schuler, G. Correction of endothelial dysfunction in chronic heart failure: additional effects of exercise training and oral L-arginine supplementation. J. Am. Coll. Cardiol., 2000, 35, 706713.

[89] Katz, S.D.; Yuen, J.; Bijou, R.; LeJemtel, T.H. Training improves endothelium-dependent vasodilation in resistance vessels of patients with heart failure. J. Appl. Physiol., 1997, 82, 1488-1492.

[90] Linke, A.; Schoene, N.; Gielen, S.; Hofer, J.; Erbs, S.; Schuler, G.; Hambrecht, R. Endothelial dysfunction in patients with chronic heart failure: systemic effects of lower-limb exercise training. $J$. Am. Coll. Cardiol., 2001, 37, 392-397.

[91] Maiorana, A.; O'Driscoll, G.; Dembo, L.; Cheetham, C.; Goodman, C.; Taylor, R.; Green, D. Effect of aerobic and resistance exercise training on vascular function in heart failure. Am. J. physiol. Heart Circ. Physiol., 2000, 279, H1999-2005.

[92] Rizzo, V.; McIntosh, D.P.; Oh, P.; Schnitzer, J.E. In situ flow activates endothelial nitric oxide synthase in luminal caveolae of endothelium with rapid caveolin dissociation and calmodulin association. J. Biol. Chem., 1998, 273, 34724-34729.

[93] Boo, Y.C.; Hwang, J.; Sykes, M.; Michell, B.J.; Kemp, B.E.; Lum, H.; Jo, H. Shear stress stimulates phosphorylation of eNOS at Ser(635) by a protein kinase A-dependent mechanism. Am. J. Physiol. Heart Circ. Physiol., 2002, 283, H1819-1828.

[94] Boo, Y.C.; Sorescu, G.; Boyd, N.; Shiojima, I.; Walsh, K.; Du, J.; Jo, H. Shear stress stimulates phosphorylation of endothelial nitricoxide synthase at Ser1179 by Akt-independent mechanisms: role of protein kinase A. J. Biol. Chem., 2002, 277, 3388-3396.

[95] Noris, M.; Morigi, M.; Donadelli, R.; Aiello, S.; Foppolo, M.; Todeschini, M.; Orisio, S.; Remuzzi, G.; Remuzzi, A. Nitric oxide synthesis by cultured endothelial cells is modulated by flow conditions. Circ. Res., 1995, 76, 536-543.

[96] Sessa, W.C.; Pritchard, K.; Seyedi, N.; Wang, J.; Hintze, T. H. Chronic exercise in dogs increases coronary vascular nitric oxide production and endothelial cell nitric oxide synthase gene expression. Circ. Res., 1994, 74, 349-353.
[97] Varin, R.; Mulder, P.; Richard, V.; Tamion, F.; Devaux, C.; Henry, J.P.; Lallemand, F.; Lerebours, G.; Thuillez, C. Exercise improves flow-mediated vasodilatation of skeletal muscle arteries in rats with chronic heart failure. Role of nitric oxide, prostanoids, and oxidant stress. Circulation, 1999, 99, 2951-2957.

[98] Widder, J.D.; Chen, W.; Li, L.; Dikalov, S.; Thony, B.; Hatakeyama, K.; Harrison, D. G. Regulation of tetrahydrobiopterin biosynthesis by shear stress. Circ. Res., 2007, 101, 830-838.

[99] Ennezat, P.V.; Malendowicz, S.L.; Testa, M.; Colombo, P.C.; Cohen-Solal, A.; Evans, T.; LeJemtel, T.H. Physical training in patients with chronic heart failure enhances the expression of genes encoding antioxidative enzymes. J. Am. Coll. Cardiol., 2001, 38, 194-198.

[100] Linke, A.; Adams, V.; Schulze, P.C.; Erbs, S.; Gielen, S.; Fiehn, E.; Mobius-Winkler, S.; Schubert, A.; Schuler, G.; Hambrecht, R. Antioxidative effects of exercise training in patients with chronic heart failure: increase in radical scavenger enzyme activity in skeletal muscle. Circulation, 2005, 111, 1763-1770.

[101] Parnell, M. M.; Holst, D. P.; Kaye, D. M., Augmentation of endothelial function following exercise training is associated with increased L-arginine transport in human heart failure. Clin. Sci. 2005, 109, 523-530.

[102] Wang, J.S.; Chow, S.E. Effects of exercise training and detraining on oxidized low-density lipoprotein-potentiated platelet function in men. Arch. Phys. Med. Rehabil., 2004, 85, 1531-1537.

[103] Anker, S.D.; Ponikowski, P.P.; Clark, A.L.; Leyva, F.; Rauchhaus, M.; Kemp, M.; Teixeira, M.M.; Hellewell, P.G.; Hooper, J.; PooleWilson, P.A.; Coats, A.J. Cytokines and neurohormones relating to body composition alterations in the wasting syndrome of chronic heart failure. Eur. Heart J., 1999, 20, 683-693.

[104] Oliff, A.; Defeo-Jones, D.; Boyer, M.; Martinez, D.; Kiefer, D.; Vuocolo, G.; Wolfe, A.; Socher, S.H. Tumors secreting human TNF/cachectin induce cachexia in mice. Cell, 1987, 50, 555-563.

[105] Adams, V.; Spate, U.; Krankel, N.; Schulze, P.C.; Linke, A.; Schuler, G.; Hambrecht, R. Nuclear factor-kappa B activation in skeletal muscle of patients with chronic heart failure: correlation with the expression of inducible nitric oxide synthase. Eur. J. Cardiovasc. Prev. Rehabil., 2003, 10, 273-277.

[106] De Sousa, E.; Veksler, V.; Bigard, X.; Mateo, P.; Ventura-Clapier, R. Heart failure affects mitochondrial but not myofibrillar intrinsic properties of skeletal muscle. Circulation, 2000, 102, 1847-1853.

[107] Fogli, S.; Nieri, P.; Breschi, M.C. The role of nitric oxide in anthracycline toxicity and prospects for pharmacologic prevention of cardiac damage. FASEB J., 2004, 18, 664-675.

[108] Gielen, S.; Adams, V.; Mobius-Winkler, S.; Linke, A.; Erbs, S.; Yu, J.; Kempf, W.; Schubert, A.; Schuler, G.; Hambrecht, R. Antiinflammatory effects of exercise training in the skeletal muscle of patients with chronic heart failure. J. Am. Coll. Cardiol., 2003, 42, 861-868

[109] Gielen, S.; Adams, V.; Linke, A.; Erbs, S.; Mobius-Winkler, S.; Schubert, A.; Schuler, G.; Hambrecht, R. Exercise training in chronic heart failure: correlation between reduced local inflammation and improved oxidative capacity in the skeletal muscle. Eur. J. Cardiovasc. Prev. Rehabil., 2005, 12, 393-400.

[110] Adamopoulos, S.; Parissis, J.; Karatzas, D.; Kroupis, C. Georgiadis, M.; Karavolias, G.; Paraskevaidis, J.; Koniavitou, K.; Coats, A.J.; Kremastinos, D.T. Physical training modulates proinflammatory cytokines and the soluble Fas/soluble Fas ligand system in patients with chronic heart failure. J. Am. Coll. Cardiol., 2002, 39, 653-663.

[111] Conraads, V.M.; Beckers, P.; Bosmans, J.; De Clerck, L.S.; Stevens, W.J.; Vrints, C.J.; Brutsaert, D.L. Combined endurance/resistance training reduces plasma TNF-alpha receptor levels in patients with chronic heart failure and coronary artery disease. Eur. Heart J., 2002, 23, 1854-1860.

[112] Niebauer, J.; Clark, A.L.; Webb-Peploe, K.M.; Coats, A.J. Exercise training in chronic heart failure: effects on pro-inflammatory markers. Eur. J. Heart Fail., 2005, 7, 189-193.

[113] Katz, S.D.; Rao, R.; Berman, J.W.; Schwarz, M.; Demopoulos, L.; Bijou, R.; LeJemtel, T.H. Pathophysiological correlates of increased serum tumor necrosis factor in patients with congestive heart failure. Relation to nitric oxide-dependent vasodilation in the forearm circulation. Circulation, 1994, 90, 12-16.

[114] Testa, M.; Yeh, M.; Lee, P.; Fanelli, R.; Loperfido, F.; Berman, J.W.; LeJemtel, T.H. Circulating levels of cytokines and their endogenous modulators in patients with mild to severe congestive 
heart failure due to coronary artery disease or hypertension. J. Am. Coll. Cardiol., 1996, 28, 964-971.

[115] Munger, M.A.; Johnson, B.; Amber, I.J.; Callahan, K.S.; Gilbert, E.M. Circulating concentrations of proinflammatory cytokines in mild or moderate heart failure secondary to ischemic or idiopathic dilated cardiomyopathy. Am. J. Cardiol., 1996, 77, 723-727.

[116] Dunlay, S.M.; Weston, S.A.; Redfield, M.M.; Killian, J.M.; Roger, V.L. Tumor necrosis factor-alpha and mortality in heart failure: a community study. Circulation, 2008, 118, 625-631.

[117] Parish, R.C.; Evans, J.D. Inflammation in chronic heart failure. Ann. Pharmacother. 2008, 42, 1002-1016.

[118] Torre-Amione, G.; Kapadia, S.; Benedict, C.; Oral, H.; Young, J. B.; Mann, D. L. Proinflammatory cytokine levels in patients with depressed left ventricular ejection fraction: a report from the Studies of Left Ventricular Dysfunction (SOLVD). J. Am. Coll. Cardiol., 1996, 27, 1201-1206.

[119] Lommi, J.; Pulkki, K.; Koskinen, P.; Naveri, H.; Leinonen, H.; Harkonen, M.; Kupari, M. Haemodynamic, neuroendocrine and metabolic correlates of circulating cytokine concentrations in congestive heart failure. Eur. Heart J., 1997, 18, 1620-1625.

[120] Abdallah, A.N.; Billes, M.A.; Attia, Y.; Doutremepuich, C.; Cassaigne, A.; Iron, A. Evaluation of plasma levels of tumour necrosis factor alpha and interleukin- 6 as rejection markers in a cohort of 142 heart-grafted patients followed by endomyocardial biopsy. Eur. Heart J. 1997, 18, 1024-1029.

[121] Mehra, M.R.; Maisel, A. B-type natriuretic peptide in heart failure: diagnostic, prognostic, and therapeutic use. Crit. Pathw. Cardiol., 2005, 4, 10-20.

[122] Nian, M.; Lee, P.; Khaper, N.; Liu, P. Inflammatory cytokines and postmyocardial infarction remodeling. Circ. Res., 2004, 94, 15431553.

[123] Haudek, S. B.; Taffet, G. E.; Schneider, M. D.; Mann, D. L., TNF provokes cardiomyocyte apoptosis and cardiac remodeling through activation of multiple cell death pathways. J. Clin. Invest., 2007, $117,2692-2701$.

(C) Mendes-Ribeiro et al:; Licensee Bentham Open.

This is an open access article licensed under the terms of the Creative Commons Attribution Non-Commercial License (http://creativecommons.org/licenses/by-nc/3.0/) which permits unrestricted, non-commercial use, distribution and reproduction in any medium, provided the work is properly cited. 